\title{
Natural Mix Algae Possible Source of Renewable Energy, Environmental friendly Bio-hydrogen
}

\author{
Muhammad Saleem Muhammad \\ Department of Civil Engineering, Jubail University College, Jubail Industrial City 31961, Saudi \\ Arabia
}

\begin{abstract}
Present study is an attempt to explore natural mix algae as a source of bio-hydrogen which is a renewable and environmental friendly clean fuel. Idea is to produce hydrogen in two stages; in first stage algae biomass is grown in light, oxygen and carbon source. In the second stage grown algae produce hydrogen in the absence of light, oxygen and sulfur. Results obtained during study showing that by using natural mix algae hydrogen up to $520 \mathrm{ml} / \mathrm{l}$ of algae biomass can be produce in one cycle. However, hydrogen gas can be produced in sufficient quantity up to three cycles. Biological hydrogen production with unicellular mix algae, found to be a promising area of research and conceptual by nature in the laboratory. This process needs to be explored more to prove the ability to use at commercial level. Still much work is required as to make process more economical and practical.
\end{abstract}

Keywords: Renewable energy, Bio-hydrogen, Algae, Anaerobic, Cyclic hydrogen production

\section{Introduction}

Rapid increase in the world population and industrializations are responsible for intensification in resources exploration including alternative energy sources. The current global energy demand is mainly dependent on fossil fuel resources which are depleting rapidly. In addition to that the world is facing severe pollution problems from the combustion of fossil fuels (Levin et al., 2004). The environmental issues related to the rate of fossil fuel uses as global warming alarm is also motivating researchers to switch from conventional fossil fuels to renewable energy sources. It is well known fact that the use of fossil resources is expanding the $\mathrm{CO}_{2}$ levels and other greenhouse gases which in turn causing the global warming (Kapdan and Kargi, 2006). At present, the $\mathrm{CO}_{2}$ concentration in the atmosphere is estimated to be more than 350 parts per million (ppm), and the increase in concentration potentially further increase the greenhouse effect (Menon and Rao, 2012). Meanwhile, it is reported that during past few decades the release of carbon by human activities is almost equal to the accumulated amount which was produced during last millions of years (Chandrasekhar et al., 2015).

Therefore, to protect the biosphere it is necessary to explore renewable and environmental friendly energy sources (Lee et al., 2014). Among other energy sources, bio-based energy is a sustainable and promising alternative to fossil fuel-based energy; due to; bio-hydrogen as a source of environmental energy it help us to handle the crisis in the energy supply and can protect the world from the approaching environmental catastrophe. In addition to, it is estimated that biological hydrogen $\left(\mathrm{H}_{2}\right)$ process has the advantages of reducing greenhouse 
emissions by 57 to 73\% (Manish and Banerjee, 2008). Hydrogen has the highest gravimetric energy density of any known fuel and is compatible with electrochemical and combustion processes for energy conversion (Levin et al., 2004). Hydrogen fuel has a high-energy yield per unit mass of $122 \mathrm{~kJ} / \mathrm{g}$, which is 2.75-fold higher than that of hydrocarbon fuels (Lin et al., 2012). Therefore, the combustion of $\mathrm{H}_{2}$ with $\mathrm{O}_{2}$ produces water as the only by-product. Consequently it is obviously favorable outcome for a reduction in GHG emissions (Chandrasekhar, et al., 2015).

Recently, biological hydrogen production from sustainable resources such as biomass, and microorganisms rather than fossil fuels, has been given considerable attention (Quintana et al., 2011). Biological production of $\mathrm{H}_{2}$ by eukaryotic algae by photosynthesis has a great interest because it holds the promise of generating a renewable fuel from abundantly available raw material (Kosourov, et al., 2003). Algae show the prospect of high biomass yields and have good potential as a source of biofuels, which can be harvested from natural stocks or cultivated in the shallow seawater (Chisti, 2007).

Recently, research on fermentative biohydrogen production using algae as a feedstock has been attracted great interest in recent years (Chandrasekhar et al., 2015). Researchers in past investigated the fermentative hydrogen production potential of various marine algae species however no one tested the natural mix algae (Jung et al., 2011).

\section{Pathways for Bio-hydrogen Production}

Discovery by Gaffron (1940) about 70 years ago showed that the unicellular algae are capable to produce hydrogen. Generally algae are oxygenic photosynthesis organisms, which can produce molecular oxygen in the presence of light. Hydrogen metabolism can't take place in anoxic environment as oxygen, it is a strong inhibitor of cellular metabolism to produce hydrogen.

However, in the dark anaerobic condition the green algae produce hydrogen using hydrogenase enzyme of cell as it mentioned by (Florin et al. 2001). In addition to that the substrate deficient in sulfur is also promotes the hydrogen production in algae. This fact is the key to produce hydrogen using algae. The concept of hydrogen production (two stages) by natural mix algae is also presented in figure 1.

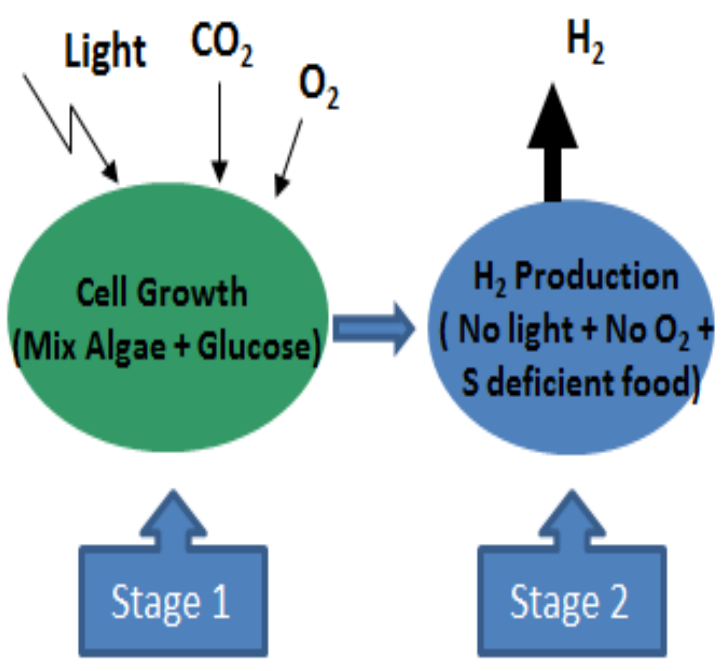

Fig. 1. Concept of two-stage $\mathrm{H}_{2}$ production by mix algae.

The advantages of producing hydrogen in the dark under anaerobic conditions are manifold, such as less incorporation of expensive accessories such as source of energy, aeration system, low maintenance costs (Dechatiwongse, 2015). This study is an attempt to explore more about the process while using natural mix algae biomass to produce hydrogen. 


\section{Material and Methods}

To evaluate the hydrogen production capability of marine natural mixed algae sample was collected from Jubail Cornish area. Batch experiments using natural mixed algae to produce hydrogen were carried out under the controlled lab condition. As algae needs a carbon source to grow, glucose as a carbon source was used to increase hydrogen productivity.

In biological hydrogen production, the basic problem is the simultaneous production of oxygen, as oxygen is a key inhibitor in the process of hydrogen production (Gaffron and Rubin, 1942). To overcome this problem the biological process split into two stages. (1) Aerobic stage or algae growth stage (2) Anaerobic stage or hydrogen production stage. The efficiency of bio hydrogen production can be increased if there is a sources of carbon like glucose. So by using carbon source that could increase the hydrogen productivity (Saleem $\boldsymbol{e t}$ al., 2012). In stage 1 the algae cells are allowed to grow in the presence of oxygen and glucose as carbon source. It was found that there is a direct relation between glucose consumption and hydrogen production. In stage 2 the cells are placed under dark condition to produce hydrogen. Sulfur deprivation is another technique to decrease the evolution of oxygen is stage 2 (Nguyen et al., 2008), as sulfur is responsible for the synthesis of protein that is a big source of oxygen, so in the absence of sulfur there is almost no chance of oxygen production. In second stage sulfur deficient growth media was provided to the natural mix algae cells. Photosynthesis and cellular metabolism of cell alter to survive by imposing sulfur scarcity during hydrogen production process (Davies $\boldsymbol{e t}$ al., 1996).

\section{Natural Marine Mix Algae}

The natural mix algae were collected from Fanateer beach, Jubail Industrial City area in a plastic container as shown in figure 2a. The growth stage of algae is shown in figure $2 \mathrm{~b}$.

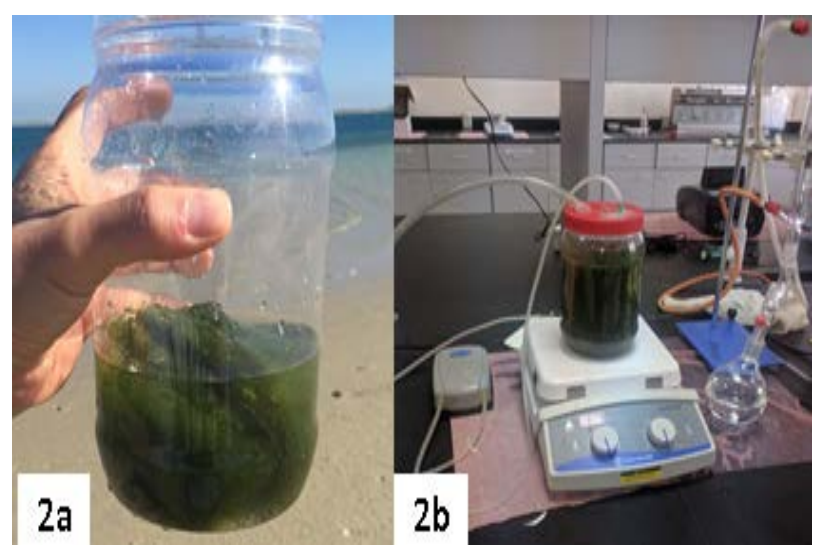

Fig. 2. Natural mix algae in laboratory, a) Sample collected, 2b) Growth phase of natural mix algae.

\section{Growth of mix algae in aerobic environment:}

In the first step the cell cultures were inoculated photoheterotrophically in sulfur medium at aerobic conditions using a china brand aquarium air pump. Medium was having an initial $\mathrm{pH}$ of 8.30 at $25{ }^{\circ} \mathrm{C}$. Culture was kept under fluorescent light during the growth stage. Fiber optic light source $(120 \mathrm{~W} / \mathrm{m} 2)$ was used for stage 1. Cell culture was allowed to grow in the medium from 2 to 5 days. Carbon source glucose was supplied in solution form of $20 \%$ solution in distilled water.

\section{Sulfur deprivation and photo-inhibition:}

In order to initiate hydrogen metabolism, natural mix algae cells which were grown in stage 1 collected and centrifuged at $3000 \mathrm{rpm}$ 
(C-5, Centrifuge, Lab Essentials) for 15-20 minutes. Cells were washed twice and resuspended in sulfur deficient media $(10 \mathrm{mM}$ K3PO4, $20 \mathrm{mM} \mathrm{KCl}$ and $2.5 \mathrm{mM} \mathrm{MgCl} 2$ solution) as reported by (Saleem at al., 2012). Cell also kept in dark during this stage to simulate the photo-inhibition condition (Ghimire, et al., 2015).

\section{Hydrogen production}

Hydrogen production was monitored and collected during the experimental runs. Hydrogen collected in first set of experimental run was measured by means of gas chromatography (GC Model 9000, PerkinElmer, USA) having a Molecular Sieve 5A column (RESTEK) that used helium as a carrier gas at a rate of $30 \mathrm{~mL} / \mathrm{min}$. The packed column was then maintained at $80{ }^{\circ} \mathrm{C}$ and the thermal conductivity detector was set to $120^{\circ} \mathrm{C}$. Later the volume of hydrogen was measured by volume displacement method in which volume of hydrogen measured equivalent to the volume of water displaced in the capillary tube.

\section{Hydrogen cycling and use of optical fiber:}

During hydrogen production stage it was found that algae exhaust after about 70 hours and need to recover before restarting the hydrogen production. Therefore, during the present work emphasized on cyclic hydrogen production also made so the cells will recover and again start producing hydrogen. The cells were transformed from stage- 2 to stage- 1 each time, so that the cells could recover their cellular activities and keep producing hydrogen. The optical fiber was introduced into the culture vessel in stage 1 and removed in stage 2 as needed.
Determination of glucose substrate concentration Concentration of glucose substrate in the system was monitored by means of periodic sampling of suspension and concentration of glucose determined after each interval of 10 hours. Blood glucose analyzer (Accu-Chek ${ }^{\circledR}$ Active, Roche) having a range of $0.6-33.3 \mathrm{mmol} / \mathrm{L}$ (10 - $600 \mathrm{mg} / \mathrm{l}$ ) was used.

\section{Results and Discussion}

Mix algae bio-mass culture and growth

As mentioned earlier, a mix-culture of algae was collected from local beach area and cells were grown in a plastic container as shown in figure 2. Air was provided by an aquarium air pump during stage 1 . Glucose was utilized as a carbon source for stage 2 . While light was provided by florescent lamp.

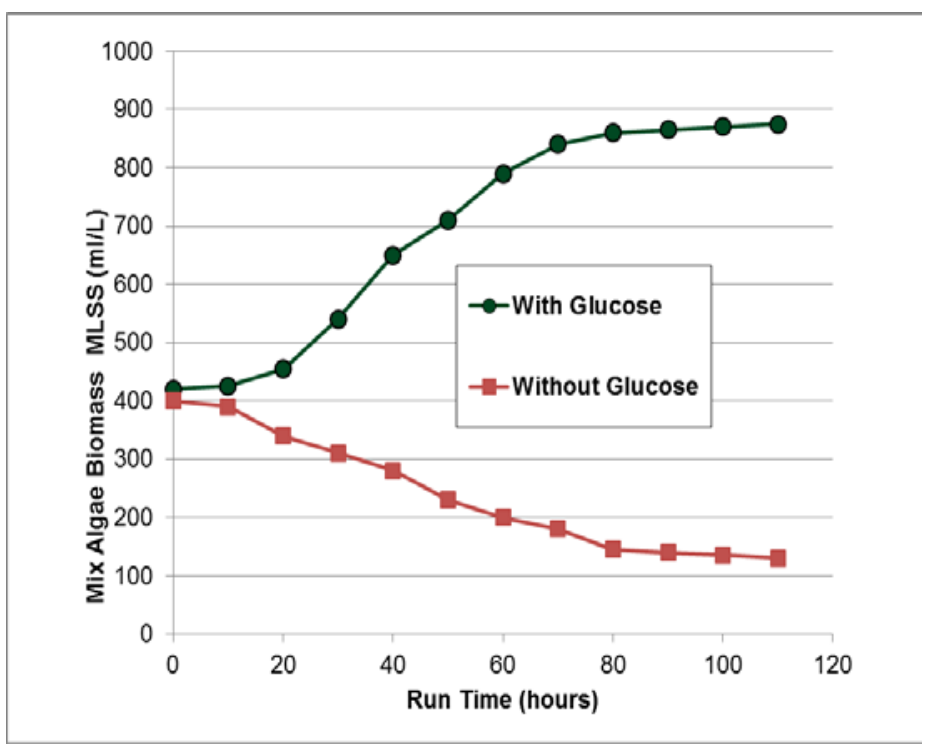

Fig. 3 Growth of natural mix algae with and without glucose substrate.

It was found that there is substantial growth of algae cells biomass which was measured by Mix Liquor Suspended Solids (MLSS) and it was increasing with the time as shown in figure 3. It can be seen from the figure that the growth 
of cells in term of MLSS decreased up to $120 \mathrm{mg} / \mathrm{l}$ MLSS after 80 hours of run when cells grown without glucose. However, when glucose was used as a substrate cells concentration reached to about $880 \mathrm{mg} / \mathrm{l}$ MLSS during same time period (80 hours of run). It means that to get better growth of algae, glucose should be added to get good growth of algae biomass.

It was found that concentration of glucose decreased during hydrogen production from 30 $\mathrm{mmol} / \mathrm{L}$ to almost zero and hydrogen production increased from zero to about 400 $\mathrm{ml} / \mathrm{l}$ of MLSS (figure 5). This showed a relationship between hydrogen production and glucose substrate utilization.

\section{Hydrogen production}

In the second stage (stage 2) culture was kept in dark and substrate was replaced with sulfur deficient media. The production of hydrogen measured with time as shown in figure 4 . Results show that the hydrogen production increases with time up to 70 hours. As the cumulative hydrogen production shows constant value means that hydrogen production is almost stopped after this time.

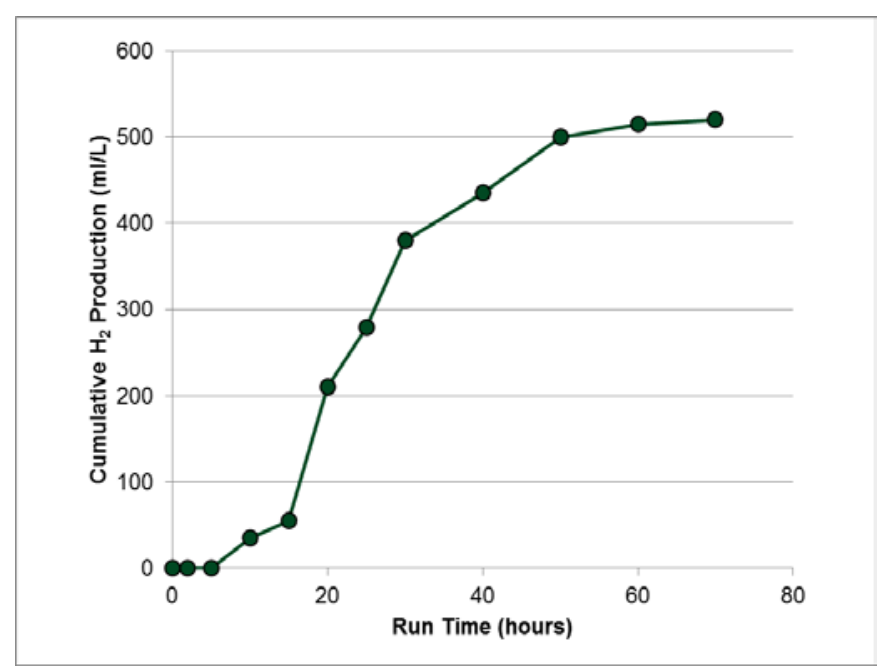

Fig. 4. Production of bio-hydrogen with time.
The utilization of substrate with the production of hydrogen was also presented in figure 5 . From figure 5 it can be seen that there is a relationship between substrate consumption and hydrogen production. Algae utilized substrate and produce hydrogen more efficiently in this stage.

It was observed that a growth period of 2 to 3 days in stage 1 was sufficient to obtain appropriate concentration for hydrogen production in stage 2 .

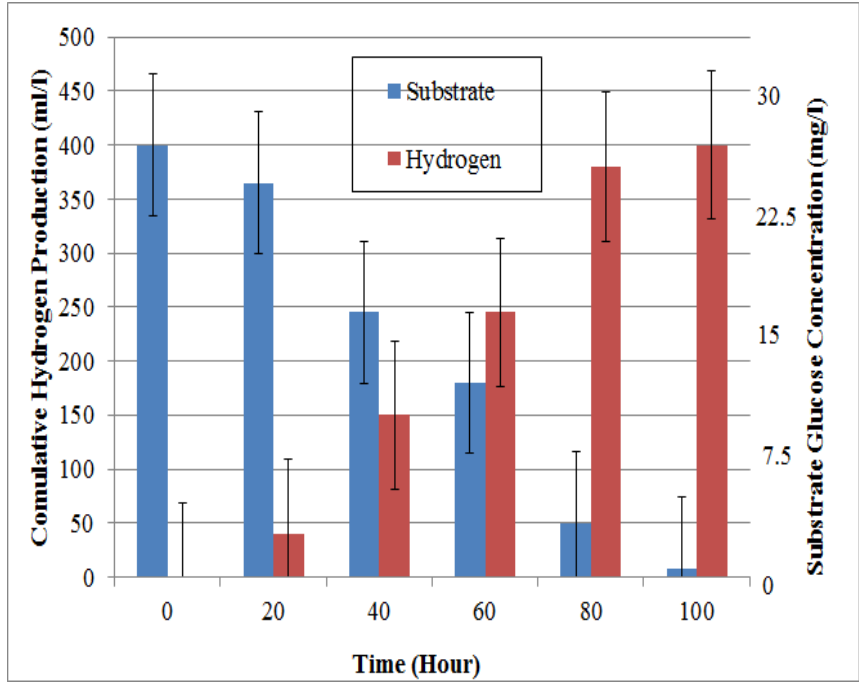

Fig. 5. Utilization of glucose substrate and production of hydrogen by natural mix algae.

Hydrogen production in cycles

As the hydrogen production efficiency of algae decrease after about 70 hours, a cyclic transformation from stage 1 to stage 2 is needed to restore the efficiency. Further study revealed that natural mix algae produced hydrogen efficiently up to three cycles in stage 2 (Fig. 6). Hydrogen was also produced in the fourth cycle but with lesser efficiency (reduced by 76\%) and a significant decrease in the production of hydrogen was observed (Fig. 6). The hydrogen 
produced in stage 2 ranged from 125 to 520 $\mathrm{mL} / \mathrm{L}$ of cell culture. Maximum volume of 520 $\mathrm{mL} / \mathrm{L}$ was observed in the first cycle while a minimum volume of $125 \mathrm{~mL} / \mathrm{L}$ was produced in the fourth cycle. This may be attributed to the limitation of natural mix algae to work under stressed environment which resulted in their exhaustion in the fourth cycle. This finding could explore an avenue for further research in order to obtain an insight for extending the number of hydrogen production cycles for economical and operational reasons.

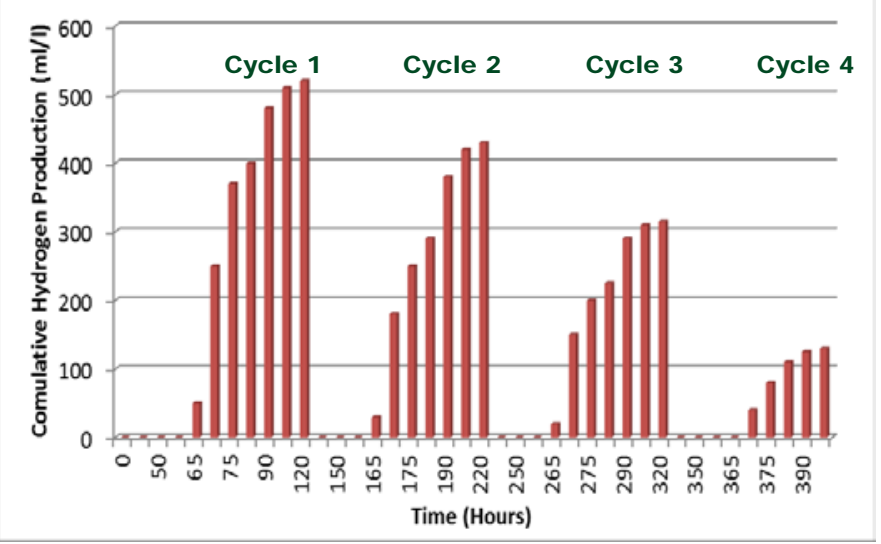

Fig. 6. Cyclic hydrogen production in two stages using natural mix algae.

\section{Conclusions and Recommendations}

Natural mix algae have excellent ability to produce bio hydrogen. Two stage process found to be a good idea to produce bio hydrogen for longer time (at least up to 320 hours) and in considerable amount. Natural mix algae work efficiently in stage 2 and produce bio-hydrogen in the absence of light and shortage of sulfur media. Natural mix algae was found to be incapable of further hydrogen production after about 70 hours. Mix algae produce hydrogen in cycles and need recovery time of about 45 to 50 hours after each cycle. It can produce hydrogen up to three cycles without large decrease in production volume. Production of hydrogen reduced dramatically in the fourth cycle. This was probably due to the limitation of Natural mix algae to work under stressful environments i.e. limited nutrients such as sulfur and/or carbon source such as glucose for long time. Use of glucose as carbon source found to be good choice to improve the hydrogen production.

Biological hydrogen production by an economical and less energy demanding technology is an advantage. However, to get a commercial level feasibility for bio hydrogen production and compare with conventional fuels, higher yields as well as higher productivity is needed.

Therefore, more research is required to increase the process efficiency and make process more economical by increasing the number of hydrogen production cycles. More research is required to find other hydrogen production sources (like algae) than mix algae to produce bio hydrogen more efficiently. Further work is needed to explore different type of carbon sources (substrate) to improve hydrogen production efficiency. More study is required to make feasibility study to make a practical hydrogen cell based on bio hydrogen production to be use for commercial purposes.

\section{References}

Chandrasekhar, K., Lee, Y. J. and Lee, D. W. (2015) Biohydrogen production: strategies to improve process efficiency through microbial routes, International journal of molecular sciences, 16, (4): 8266-8293.

Chisti, Y. (2007) Biodiesel from microalgae, Biotechnology advances, 25, (3): 294-306.

Davies, J. P., Yildiz, F. H. and Grossman, A. (1996) Sac1, a putative regulator that is critical for survival of Chlamydomonas reinhardtii during sulfur deprivation, The EMBO journal, 15, (9), 2150. 
Dechatiwongse, P. (2015) A Study of the Growth and Hydrogen Production of Cyanothece sp. ATCC 51142, Doctoral dissertation, Imperial College London.

Florin, L., Tsokoglou, A. and Happe, T. (2001) A Novel Type of Iron Hydrogenase in the Green AlgaScenedesmus obliquus Is Linked to the Photosynthetic Electron Transport Chain, Journal of Biological Chemistry, 276, (9): 6125-6132.

Gaffron, H. (1940) Carbon dioxide reduction with molecular hydrogen in green algae, American Journal of Botany, 273283.

Gaffron, H. and Rubin, J. (1942) Fermentative and photochemical production of hydrogen in algae, The Journal of General Physiology, 26, (2): 219-240.

Ghimire, A., Frunzo, L., Pirozzi, F., Trably, E., Escudie, R., Lens, P. N. and Esposito, G. (2015) A review on dark fermentative biohydrogen production from organic biomass: process parameters and use of by-products, Applied Energy, 144: 73-95.

Jung, K. W., Kim, D. H., Kim, S. H. and Shin, H. S. (2011) Bioreactor design for continuous dark fermentative hydrogen production, Bioresource technology, 102, (18): 8612-8620.

Kapdan, I. K. and Kargi, F. (2006) Bio-hydrogen production from waste materials, Enzyme and microbial technology, 38, (5): 569-582.

Kosourov, S., Seibert, M. and Ghirardi, M. L. (2003) Effects of extracellular $\mathrm{pH}$ on the metabolic pathways in sulfurdeprived, H2-producing Chlamydomonas reinhardtii cultures, Plant and Cell Physiology, 44, (2): 146-155.

Lee, S. J., Lee, S. J. and Lee, D. W. (2014) Design and development of synthetic microbial platform cells for bioenergy, Synthetic biology applications in industrial microbiology, 87.
Levin, D. B., Pitt, L. and Love, M. (2004) Biohydrogen production: prospects and limitations to practical application, International journal of hydrogen energy, 29, (2): 173-185.

Lin, C. Y., Lay, C. H., Sen, B., Chu, C. Y., Kumar, G., Chen, C. C. and Chang, J. S. (2012) Fermentative hydrogen production from wastewaters: a review and prognosis, International Journal of hydrogen energy, 37, (20): 1563215642.

Manish, S. and Banerjee, R. (2008) Comparison of biohydrogen production processes, International Journal of Hydrogen Energy, 33, (1): 279-286.

Menon, V. and Rao, M. (2012) Trends in bioconversion of lignocellulose: biofuels, platform chemicals \& biorefinery concept, Progress in Energy and Combustion Science, 38, (4): 522-550.

Nguyen, A. V., Thomas-Hall, S. R., Malnoë, A., Timmins, M., Mussgnug, J. H., Rupprecht, J. and Schenk, P. M. (2008) Transcriptome for photobiological hydrogen production induced by sulfur deprivation in the green alga Chlamydomonas reinhardtii, Eukaryotic cell, 7, (11): 19651979.

Quintana, N., Van der Kooy, F., Van de Rhee, M. D., Voshol, G. P. and Verpoorte, R. (2011) Renewable energy from Cyanobacteria: energy production optimization by metabolic pathway engineering, Applied microbiology and biotechnology, 91, (3): 471-490.

Saleem, M, Chakrabarti, M.H., Rahman, A. A. A, Diya'uddeen, B. H., Daud, W. M. W. A. and Mustafa, A. (2012) Hydrogen production by Chlamydomonas reinherdtii in a two stage process with and without illumination at alkaline $\mathrm{pH}$, International Journal of Hydrogen Energy, Elsevier, 37, (6): 4930-4934.

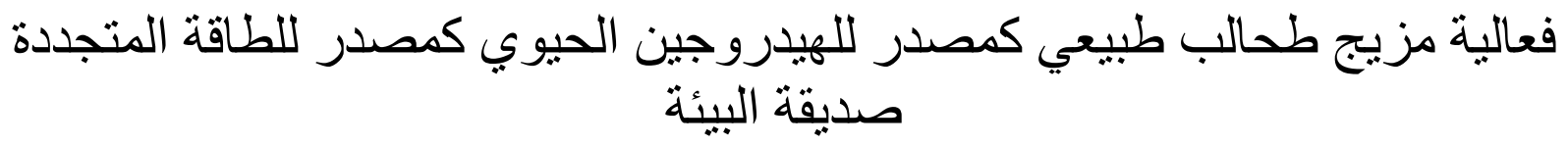




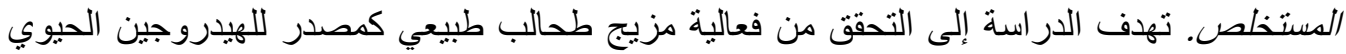

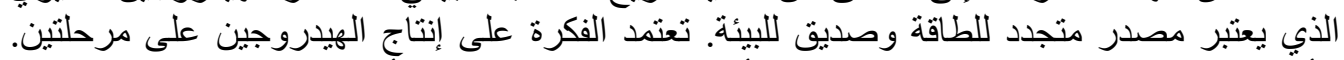

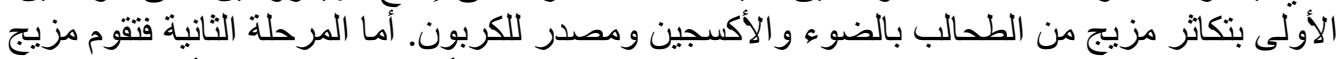

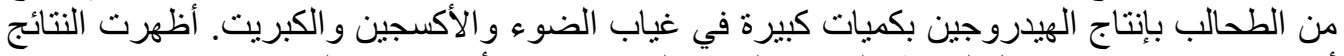

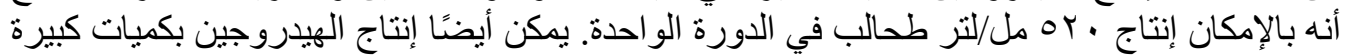

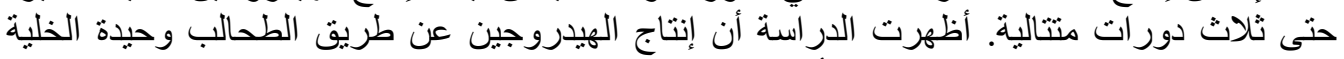

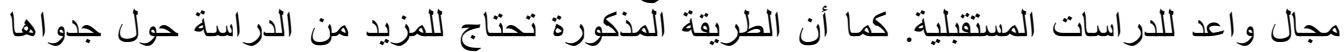

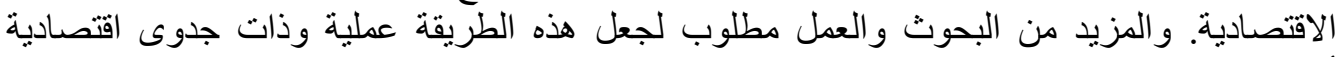

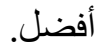

الكلمات المفتاحية: الطاقة المتجددة، البايو هيدروجين، البكتيريا، المفاعل اللاهو ائي، إنتاج الهيدروجين. 